\title{
HEPATOPROTECTIVE EVALUATION OF EPALTES DIVARICATA (L.) CASS. WHOLE PLANT EXTRACTS AGAINST PARACETAMOL-INDUCED HEPATOTOXICITY IN RATS
}

\author{
K. AMALA ${ }^{1 *}$, R. ILAVARASAN ${ }^{1}$, R. ARUNADEVI ${ }^{1}$, S. AMERJOTHY ${ }^{2}$ \\ ${ }^{1}$ Captain Srinivasa Murti Regional Ayurveda Drug Development Institute (CCRAS), Anna Hospital Campus, Arumbakkam, Chennai 600106, \\ India, ${ }^{2}$ Departmentof Plant Biology and Plant Biotechnology, Presidency College, Chennai, India \\ Email: amalavenkey@gmail.com \\ Received: 30 Aug 2016 Revised and Accepted: 18 0ct 2016
}

\section{ABSTRACT}

Objective: The plant of Epaltes divaricata (L.) Cass. Traditionally used for jaundice. The present work aimed to investigate the hepatoprotective activity of alcohol and aqueous extract of the whole plant against paracetamol-induced hepatotoxicity in rats to substantiate its traditional use.

Methods: The alcohol and aqueous (200 and $400 \mathrm{mg} / \mathrm{kg}$ ) extract of Epaltes divaricata prepared by cold maceration were administered orally to the animals with hepatotoxicity induced by paracetamol $(1000 \mathrm{mg} / \mathrm{kg})$. Silymarine $(40 \mathrm{mg} / \mathrm{k})$ was given as reference standard. Hepatoprotective activity was assessed by estimating marker enzymes and by histopathological studies.

Results: Both alcohol and aqueous (200 and $400 \mathrm{mg} / \mathrm{kg}$ ) extract treatment significantly restored the paracetamol-induced elevations in levels of serum enzymes aspartate transaminase (AST), alanine transaminase (ALT), alkaline phosphate (ALP) and total bilirubin in a dose-dependent manner. Histopathological examination revealed that the treatment attenuated the paracetamol-induced damage to the liver. The hepatoprotective effect of both extracts was comparable to that of the standard hepatoprotective agent, silymarin.

Conclusion: The alcohol and aqueous extract of E. divaricata exhibited hepatoprotective effect against paracetamol-induced liver damage in rats. This study also validated their traditional medicinal use in jaundice.

Keywords: Epaltes divaricata, Alcohol and Aqueous extract, Paracetamol, Hepatoprotection

(c) 2016 The Authors. Published by Innovare Academic Sciences Pvt Ltd. This is an open access article under the CC BY license (http://creativecommons.org/licenses/by/4. 0/) DOI: http://dx.doi.org/10.22159/ijpps.2016v8i12.14951

\section{INTRODUCTION}

Liver disease is still a worldwide health problem. Unfortunately, conventional or synthetic drugs used in the treatment of liver diseases are inadequate and sometimes can have serious side effect [1]. In spite of tremendous advances in modem medicine, there are hardly any reliable drugs that protect the liver from damage and help in regeneration of hepatic cell. Herbal drugs play a major role in the treatment of hepatic disorders. A number of medicinal plants and their formulations are widely used for the treatment of these disorders. Many active plant extracts are frequently utilized to treat a wide variety of clinical diseases including liver disease. Therefore, searching for effective and safe drugs for liver disorders are continues to be an area of interest [2]. According to World Health Organization, medicinal plants are the best source to obtain newer herbal drugs. About $80 \%$ of individuals from developed countries use traditional medicine, which has compounds derived from medicinal plants. Therefore, such plants should be investigated for a better understanding of their properties, safety, and efficacy [3]. In developing countries plants are used for various ailments.

The plant of Epaltes divaricata (L.) Cass. Commonly known as kakkaranthai in Tamil belongs to the family Asteraceae and the genus Epaltes [4-6]. It is traditionally used by the people in Sri Lanka for treating jaundice, urethral discharges and acute dyspepsia. It is also regarded as a diaphoretic, diuretic and a stimulating expectorant [7]. Epaltes divaricata is widely used in Sri Lanka as an ayurvedic medicine and also as a delicacy in villages [8]. The roots are used as astringent and tonic [9]. The chemical constituents of five closely related eudesmane derivatives have been isolated from the acetone extract of this plant [10]. The aqueous extract of $E$. divaricata showed a decrease in the hepatic injury in rats as evident by serum liver enzyme profile and histopathological evaluation against $\mathrm{CCl}_{4}$-induced liver damage [8]. No systematic study has been reported in an acute liver damage model like paracetamol-induced hepatotoxicity in rats for this plant. The present study has been undertaken with the aim to determine the hepatoprotective activity of the aqueous and alcohol extract of Epaltes divaricata.

\section{MATERIALS AND METHODS}

\section{Plant material}

The whole fresh plant of E. divaricata was collected from Thirunelveli district of Tamil Nadu, India in the month of February. The plant was identified and authenticated by Taxonomist Dr. S. Amerjothy, retired Dean of Science and Head of the Dept., Department of plant biology and plant biotechnology, Presidency College, Chennai 600005. Herbarium of E. divaricata (00629) was prepared and deposited in Captain Srinivasa Murti Research Institute for Ayurveda and Siddha Drug Development, Chennai for future reference.

\section{Preparation of plant extracts}

The freshly collected whole plant materials of E. divaricata were cut into small pieces, shade dried and coarsely powdered. The powdered plant material $(100 \mathrm{~g})$ was extracted with alcohol (95\%) and aqueous (distilled water) respectively by cold maceration method for $48 \mathrm{~h}$. The respective extracts were concentrated under reduced pressure to obtain a semi-solid mass and were kept under the refrigeration. These extracts were screened for hepatoprotective activity.

\section{Chemicals}

Paracetamol (acetaminophen) was procured from Icars health care, Chennai. Silymarin was purchased from a local pharmacy, Chennai manufactured by Micro labs limited and test kits were procured from E-Merck, India Ltd, Mumbai. All other reagents used for the experiments were of analytical grade. Merck micro lab $200 \mathrm{semi}$ auto analyser was used for the estimation of biochemical parameters.

\section{Experimental animals}

Healthy albino rats of Wistar strain weighing 100-150 g of either sex were used for the experiments. The animals were purchased from Tamil Nadu, Veterinary and Animal Science University, Chennai, 
Tamilnadu. Protocols were approved by the Institutional Animal Ethics Committee (IAEC approval No: IAEC/CSMDRIA/04/2010). The rats were maintained at prevailing ambient temperature, humidity and exposed to natural day and night cycles. The animals were given pellet diet and RO water ad libitum.

\section{Phytochemical analysis}

The extracts of E. divaricata were subjected to the preliminary phytochemical analysis for the presence/absence of different phytoconstituents by using the standard phytochemical tests [11-13].

\section{Acute toxicity study}

An acute oral toxicity study was conducted according to OECD guidelines (Acute toxic class method) 423 [14]. The acute oral toxicity study of aqueous and alcoholic extracts of the plant was determined in Wistar strain of albino rats (100-150 g) of female sex which fasted overnight and provided with water ad libitum and divided into 4 groups of three animals each. Since the plant is used in ethno culinary practice, the aqueous and alcoholic extracts of $E$. divaricata were administered orally with a limit dose of $2000 \mathrm{mg} / \mathrm{kg}$ body weight to three animals in each group.

The following observations were made during the course of the study. Clinical signs and mortality after dosing at 30 min intervals up to $4 \mathrm{~h}$ of dosing and daily thereafter for a total of $14 \mathrm{~d}$. Body weight was recorded on treatment day 1 and post-treatment days 7 and 14 . The absence of apparent toxicity was further confirmed by dosing another three animals in the respective group.

Hence we did not observe any toxicity at $2000 \mathrm{mg} / \mathrm{kg}$ body weight, the doses $200(1 / 10$ th of 2000) and $400(1 / 5$ th of 2000) mg/kg body weight (p. o) was selected for this study.

\section{Drugs}

Paracetamol was used to induce hepatotoxicity; silymarin was used as a reference control for hepatoprotective activity against the paracetamol-induced model. Aqueous and alcoholic extracts were suspended with $1 \%$ Tween 80 to make a uniform suspension, paracetamol and silymarin were suspended with $1 \%$ sodium carboxyl methyl cellulose (SCMC) before administration.

\section{Hepatoprotective activity}

The rats were divided into 7 groups of either sex comprising 6 animals each. All the animals except control group were intoxicated with paracetamol $(1 \mathrm{~g} / \mathrm{kg}$ po) daily for $7 \mathrm{~d}$. The test drugs were administered to rats orally. Group-I served as control received 1\% Tween $80(10 \mathrm{ml} / \mathrm{kg}$ po $)$ once daily for $12 \mathrm{~d}$. Group-II served as hepatotoxic control administered with paracetamol $(1 \mathrm{~g} / \mathrm{kg} \mathrm{po})$ daily for first $7 \mathrm{~d}$. Group-III served as reference control received paracetamol $(1 \mathrm{~g} / \mathrm{kg}$ po) daily for first $7 \mathrm{~d}$ and silymarin administered from $4^{\text {th }}$ day to $12^{\text {th }}$ day ( $40 \mathrm{mg} / \mathrm{kg}$ po). Group-IV and V received paracetamol $(1 \mathrm{~g} / \mathrm{kg}$ po) daily for first $7 \mathrm{~d}, E$. divaricata aqueous extract ( 200 and $400 \mathrm{mg} / \mathrm{kg}$ po respectively) administered from $4^{\text {th }}$ day to $12^{\text {th }}$ day once daily. Group-VI and VII received paracetamol $(1 \mathrm{~g} / \mathrm{kg}$ po) once daily for first $7 \mathrm{~d}$, an alcohol extract of E. divaricata (200 and $400 \mathrm{mg} / \mathrm{kg}$ po respectively) administered from $4^{\text {th }}$ day to $12^{\text {th }}$ day thirty minutes after administration of paracetamol. On day 13 types of blood was collected from all animals before sacrifice under light ether anesthesia by retro-orbital puncture and allowed to coagulate for $30 \mathrm{~min}$ at $37{ }^{\circ} \mathrm{C}$ and centrifuged to obtain serum.

Clear serum was used for estimation of various biochemical parameters such as aspartate transaminase (AST), alanine transaminase (ALT), alkaline phosphatase (ALP) and total bilirubin. After collecting blood samples, the animals were sacrificed by cervical dislocation and the liver was dissected out, rinsed in ice-cold saline. A portion of liver tissues was fixed in $10 \%$ formalin, dehydrated in graded alcohol and then embedded in paraffin. Microtome sections ( $6 \mu \mathrm{m}$ thick) were prepared from each liver sample and stained with haemotoxylin-eosin dye.

The sections were examined for the pathological findings of hepatotoxicity [15]. Liver damage was assessed by the estimation of serum activities of AST, ALT and ALP and bilirubin using suitable standard kits $[16,17,18-20,21]$. Histopathological assessment of liver damage was done by studying hematoxylin and eosin stained slides of liver tissue.

\section{Statistical analysis}

The data were expressed as mean \pm SD. The statistical analysis was carried out using one-way ANOVA with Tukey multiple comparison posttest. $P$ values $<0.05$ was considered significant.

\section{RESULTS}

\section{Phytochemical screening}

In the present study alcoholic (yield $14 \% \mathrm{w} / \mathrm{w}$ ) and aqueous (yield $16 \% \mathrm{w} / \mathrm{w}$ ) extracts of $E$. divaricata were subjected to preliminary phytochemical tests. Results revealed the presence of amino acids, coumarin, flavonoid, steroid, phenol, tannin, sugar and triterpenoids, the result were shown in table 1.

Table 1: Preliminary phytochemical screening of Epaltes divaricata

\begin{tabular}{lll}
\hline Phytochemicals & Test & Alcohol extract \\
\hline Amino acids & Ninhydrin test & + \\
Coumarin & Sodium hydroxide test & + \\
Flavonoid & Shinoda's test & + \\
Glycoside/Sugar & Molisch's test & + \\
& Fehling's test & + \\
& Benedict's test & + \\
Phenol & Anthrone-sulphuric acid test & + \\
Steroid & Ferric chloride test & + \\
& Libermann-Burchard test & + \\
Tannin & Salkowski test & + \\
& Ferric chloride test & + \\
Triterpenoid & Lead acetate test & + \\
\end{tabular}

$+\rightarrow$ Present; $\rightarrow$ Absent

\section{Acute toxicity study}

In the acute toxicity study, both alcoholic and aqueous extracts of $E$ divaricata were found to be apparently nontoxic at the dose of 2000 $\mathrm{mg} / \mathrm{kg}$.

\section{Effect of the extracts on serum marker enzyme levels}

The result of the effect of aqueous and alcohol extracts (at the dose level of 200 and $400 \mathrm{mg} / \mathrm{kg}$ respectively) on serum marker enzymes were shown in table 2. Assessment of liver function was made by 
estimating the activities of serum marker enzymes AST, ALT, ALP and total bilirubin. The table also shows the comparison of effects among the untreated (control) and paracetamol treated negative control), silymarin treated (positive control) group along with the extracts treated groups.

\section{Paracetamol control (Group II)}

There was a significant $(\mathrm{P}<0.001)$ increase in the serum level of total bilirubin $(0.71 \pm 011 \mathrm{mg} / \mathrm{dl})$, AST $(289.33 \pm 38.92 \mathrm{IU} / \mathrm{l})$, ALT $(113.5 \pm 19.36 \mathrm{IU} / \mathrm{l})$, and ALP $(747 \pm 80.46 \mathrm{IU} / \mathrm{l})$ as shown in table 2 .

\section{Reference drug silymarin treatment (Group III)}

There was a significant decrease in total bilirubin $(0.28 \pm 0.04$ $\mathrm{mg} / \mathrm{dl}$ ) accompanied by significant decrease in the level of AST $(109 \pm 28.92 \mathrm{IU} / \mathrm{l})$ and also a significant decrease in ALP $(525.33 \pm 18.61 \mathrm{IU} / \mathrm{l})$ and ALT $(60.5 \pm 8.19 \mathrm{IU} / \mathrm{l})$ as compared to the Paracetamol control.

\section{Aqueous extract low dose treatment (Group IV)}

There was a significant decrease in total bilirubin $(0.2 \pm 0.06 \mathrm{mg} / \mathrm{dl})$ accompanied by significant decrease in the level of AST $(98.83 \pm 46.58 \mathrm{IU} / \mathrm{l})$ and also a significant decrease in ALT
(65.40 $\pm 8.06 \mathrm{IU} / \mathrm{l})$ and ALP $(602.83 \pm 21.98 \mathrm{IU})$ as compared to the Paracetamol control.

\section{Aqueous extract high dose treatment (Group V)}

There was a significant decrease in total bilirubin $(0.32 \pm 0.04$ $\mathrm{mg} / \mathrm{dl}$ ), accompanied by significant decrease in the level of AST $(155.45 \pm 43.14 \mathrm{IU} / \mathrm{l})$ and also a significant decrease in ALT $(78.66 \pm 8.91 \mathrm{IU} / \mathrm{l})$ and ALP $(524.66 \pm 78.90 \mathrm{IU} / \mathrm{l})$ as compared to the Paracetamol control.

\section{Alcohol extract low dose treatment (Group VI)}

There was a significant decrease in total bilirubin $(0.3 \pm 0.0 \mathrm{mg} / \mathrm{dl})$, accompanied by significant decrease in the level of AST $(124.06 \pm 23.94 \mathrm{IU} / \mathrm{l})$ and also a significant decrease in ALT $(66.22 \pm 3.60 \mathrm{IU} / \mathrm{l})$ and ALP $(478.16 \pm 158.19 \mathrm{IU} / \mathrm{l})$ as compared to the Paracetamol control.

\section{Alcohol extract high dose treatment (Group VII)}

There was a significant decrease in total bilirubin $(0.26 \pm 0.08$ $\mathrm{mg} / \mathrm{dl}$ ), accompanied by significant decrease in the level of AST $(117.5 \pm 29.89 \mathrm{mg} / \mathrm{l})$ and also a significant decrease in ALT $(57.2 \pm 5.30 \mathrm{IU} / \mathrm{l})$ and ALP $(580.16 \pm 11.61 \mathrm{IU} / \mathrm{l})$ as compared to the Paracetamol control.

Table 2: Effect of aqueous and alcohol extract of Epaltes divaricata on serum biochemical parameters of paracetamol-induced hepatotoxicity in rats

\begin{tabular}{|c|c|c|c|c|c|}
\hline Groups & $\begin{array}{l}\text { Dose } \\
(\mathrm{mg} / \mathrm{kg})\end{array}$ & $\begin{array}{l}\text { Aspartate } \\
\text { transaminase }(U / 1)\end{array}$ & $\begin{array}{l}\text { Alanine } \\
\text { transaminase }(U / 1)\end{array}$ & $\begin{array}{l}\text { Alkaline phosphate } \\
(\mathrm{U} / \mathrm{l})\end{array}$ & $\begin{array}{l}\text { Total Bilirubin } \\
(\mathrm{mg} / \mathrm{dl})\end{array}$ \\
\hline Control (Normal) & $10 \mathrm{ml}$ & $149 \pm 32.09$ & $76.5 \pm 16.64$ & $518.83 \pm 46.87$ & $0.28 \pm 0.04$ \\
\hline Paracetamol control & $1 \mathrm{~g}$ & $289.33 \pm 38.92 \dagger+\dagger$ & $113.5 \pm 19.36 \dagger+\dagger$ & $747 \pm 80.46 \dagger+\dagger$ & $0.71 \pm 0.11 \dagger+\dagger$ \\
\hline Paracetamol+Silymarin & 40 & $109 \pm 28.92^{* * *}$ & $60.5 \pm 8.19^{* * *}$ & $525.33 \pm 18.61^{* * *}$ & $0.28 \pm 0.04^{* * *}$ \\
\hline $\begin{array}{l}\text { Paracetamol }+E \text {. divaricata } \\
\text { (Aqueous extract) }\end{array}$ & 200 & $98.83 \pm 46.58^{* * *}$ & $65.40 \pm 8.06^{* * *}$ & $602.83 \pm 21.98^{*}$ & $0.2 \pm 0.06^{* * *}$ \\
\hline $\begin{array}{l}\text { Paracetamol }+E \text {. divaricata } \\
\text { (Aqueous extract) }\end{array}$ & 400 & $155.45 \pm 43.14^{* * *}$ & $78.66 \pm 8.91^{* * *}$ & $524.66 \pm 78.90^{* * *}$ & $0.32 \pm 0.04^{* * *}$ \\
\hline $\begin{array}{l}\text { Paracetamol+E. divaricata } \\
\text { (Alcohol extract) }\end{array}$ & 200 & $124.06 \pm 23.94^{* * *}$ & $66.22 \pm 3.60^{* * *}$ & $478.16 \pm 158.19 * *$ & $0.3 \pm 0.0^{* * *}$ \\
\hline $\begin{array}{l}\text { Paracetamol }+E \text {. divaricata } \\
\text { (Alcohol extract) }\end{array}$ & 400 & $117.5 \pm 29.89 * * *$ & $57.2 \pm 5.30^{* * *}$ & $580.16 \pm 11.61^{* * *}$ & $0.26 \pm 0.08^{* * *}$ \\
\hline
\end{tabular}

Values are mean $\pm \mathrm{SD}$ for 6 animals in each group. $\dagger \dagger \dagger \mathrm{P}<0.001$ considered significant (comparisons were made between Group I vs Groups II). ${ }^{*} \mathrm{P}<0.05{ }^{* *} \mathrm{P}<0.01,{ }^{* * *} \mathrm{P}<0.001$ considered significant (comparisons were made between Group II vs Groups III to VII)

\section{Histopathology}

Histopathological studies also supported the finding of biochemical analysis. The liver sections of the normal control group animal showed (fig. 1) normal architecture with the central vein. In rats treated with paracetamol, the intoxicated group showed (fig. 2) disturbance in the lobular arrangement, ballooning degeneration, centrizonal necrosis and extensive degeneration of hepatocytes. In silymarin treated rat's histopathology of the liver revealed normal architecture with central vein and less amount of necrosis (fig. 3 ). Rats treated with aqueous extract of E. divaricata (200 and 400 $\mathrm{mg} / \mathrm{kg}$ ) showed mild degeneration, sinusoidal dilation and binucleated cells (fig. 4, 5). The alcohol extract of E. divaricata $(200$ and $400 \mathrm{mg} / \mathrm{kg}$ ) treated rats showed mild degeneration, ballooning, binucleated cells and fatty changes (fig.6,7). Overall improvement was observed in the architecture of liver in extracts treated groups.

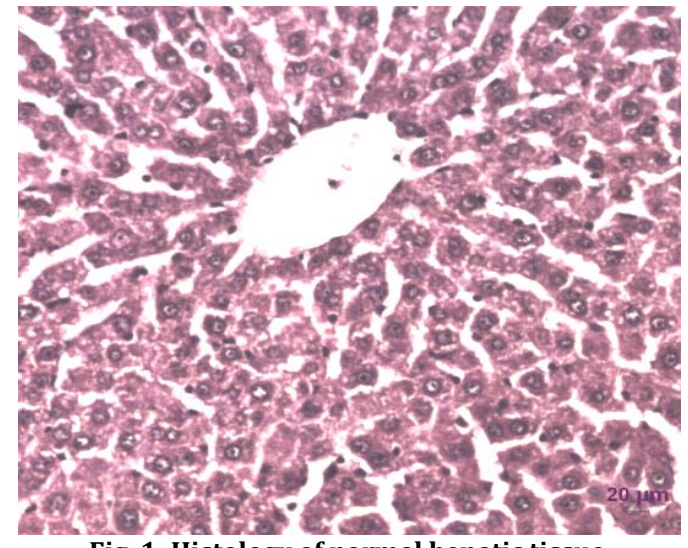

Fig. 1: Histology of normal hepatic tissue

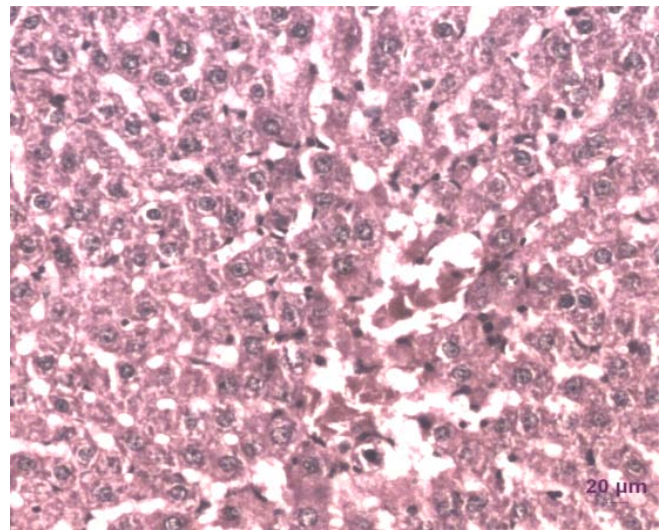

Fig. 2: Paracetamol induced damage in hepatic tissue 


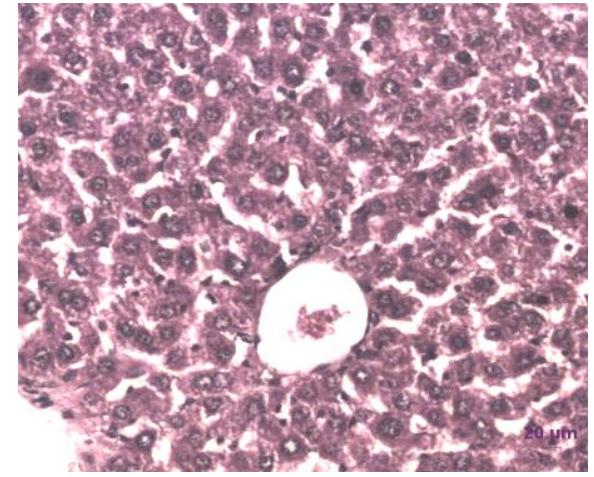

Fig. 3: Effect of Silymarin On paracetamol induced damage

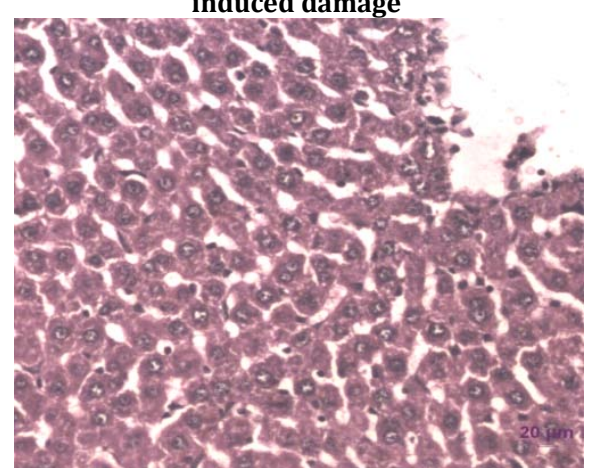

Fig. 5: Effect of AqEEd (400 mg/kg) On paracetamol induced hepatic damage

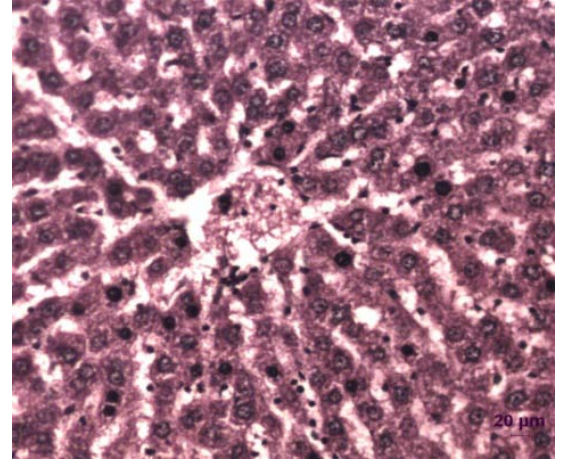

Fig. 4: Effect of AqEEd (200 mg/kg) On paracetamol induced

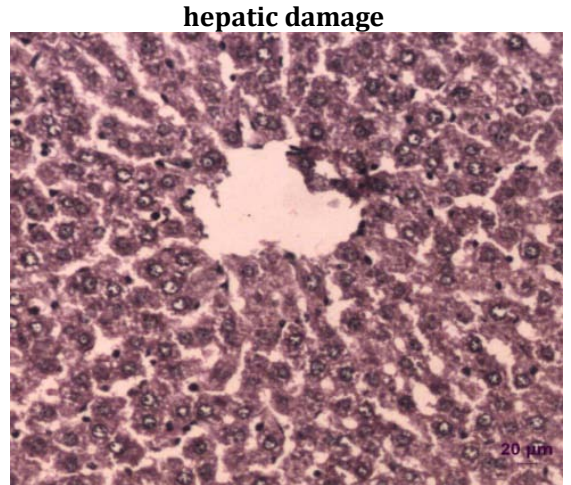

Fig. 6: Effect of AlEEd $(200 \mathrm{mg} / \mathrm{kg})$ On paracetamol induced hepatic damage

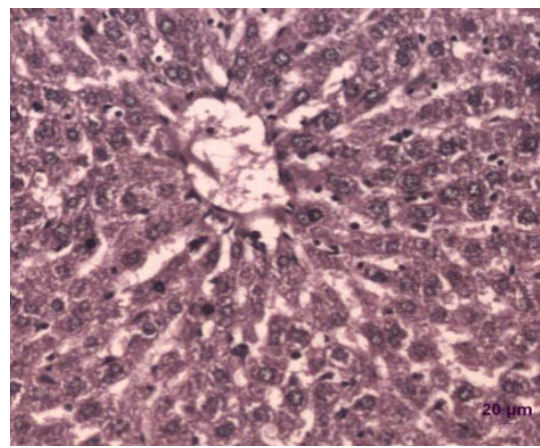

Fig. 7: Effect of AlEEd (400 mg/kg) On paracetamol induced hepatic damage

\section{DISCUSSION}

Preliminary phytochemical screening on medicinal plant an important in the detection of bioactive principles which is a new source of therapeutically and industrially valuable compounds that may lead to drugs discovery and development [22]. Phytoconstituents like carbohydrates, proteins, phenol, flavonoid, and tannin seemed to have a potent drug for various diseases [23]. Plant extracts can be used as alternative drugs to treat the diseases caused by pathogens [24]. In this study, the plant extracts of Epaltes divaricata revealed the presence of tannins, Amino acids, flavonoids, phenol, and triterpenoids might be attributed to the medicinal characteristics of this plant.

Paracetamol hepatotoxicity is caused by the reaction metabolite $\mathrm{N}$ acetyl- $p$-benzoquinone imine, which causes oxidative stress and glutathione depletion. It is a well-known antipyretic and analgesic agent, which produces hepatic necrosis at higher doses [25]. Paracetamol toxicity is due to the formation of toxic metabolites when a part of it is metabolized by cytochrome $\mathrm{P}_{450}$. Induction of cytochrome [26] or depletion of hepatic glutathione is a prerequisite for paracetamol induced hepatotoxicity [27]. PCM administration also causes necrosis of the centrilobular hepatocytes characterized by nuclear pyknosis and eosinophilic cytoplasm followed by the large excessive hepatic lesion. The covalent binding of NAPQI to sulphydryl groups of protein results in lipid peroxidative degradation of GSH level and thereby produces cell necrosis in the liver [2]. Assessment of liver function can be made by estimating the activities of serum ALT, AST, ALP and level of total bilirubin. All these marker enzymes are originally present in higher concentration in the cytoplasm. When there is hepatopathy, these enzymes leak into the bloodstream which serves as an indicator for the liver damage. Rats treated with paracetamol developed significant damage in the liver as seen from altered levels of hepatospecific enzymes and bilirubin.

In the present study, we observed that the levels of serum marker enzymes AST, ALT, ALP and total bilirubin were significantly $(\mathrm{P}<0.001)$ increased in paracetamol treated rats when compared to vehicle control rats. Since the damage of paracetamol metabolite is through oxidative stress and depletion of reducing agents, phytoconstituents like phenolics and flavonoids might play a role in counteracting the toxic effect. The aqueous and alcoholic extracts $(200$ and $400 \mathrm{mg} / \mathrm{kg})$ treated animals showed significant $(\mathrm{P}<0.001)$ reduction in AST, ALT and total bilirubin when compared to paracetamol treated rats. The higher dose $(400 \mathrm{mg} / \mathrm{kg})$ of both extracts produced a significant $(\mathrm{P}<0.001)$ reduction in ALP when compared to paracetamol treated rats, the lower dose $(200 \mathrm{mg} / \mathrm{kg})$ also produced a significant $(\mathrm{P}<0.05, \mathrm{P}<0.01)$ reduction in $A L P$, but it was less effective compared to higher dose. Standard drug silymarin $(40 \mathrm{mg} / \mathrm{kg})$ treated rats also showed significant $(\mathrm{P}<0.001)$ reduction in AST, ALT, ALP and bilirubin levels when compared to paracetamol 
treated rats. Histopathological examination of the liver tissues also supported the hepatoprotection. Paracetamol is induced liver necrosis was inhibited significantly by the plant extracts, which confirms the protection action of the alcoholic and aqueous extract of E. divaricata against experimentally induced liver damage in rats.

\section{CONCLUSION}

It can be concluded that the data obtained in the present study suggested that the aqueous and alcoholic extracts of E. divaricato showed significant hepatoprotective activity against paracetamol induced hepatic injury in a dose-dependent manner. In our observation preliminary phytochemical screening of the extracts of E. divaricata revealed the presence of amino acids, coumarin, flavonoid, steroid, phenol, tannin, sugar, and triterpenoids. These secondary metabolites are an important source to produce the plant-based medicines. TLC and HPTLC fingerprints in a different solvent of this plant revealed few chemical components [28]. Eleven constituents were identified from an n-hexane extract of this plant by GC-MS analysis, major constituents of $n$-hexadecanoic acid and 9,12 octadecanoic acid have been reported [29], these compounds possess many biological activities. A number of scientific reports indicate that n-Hexadecanoic acid palmitic acid and 9, 12octadecadienoic acid (Z, Z)-linoleic acid possess antioxidant, hypocholesterolemic, hepatoprotective, antihistaminic and 5-Alpha reductase inhibitor activities [30]. The presence of these compounds in the plant extract might be responsible for the hepatoprotective activity of this plant.

\section{ACKNOWLEDGEMENT}

Authors are thankful to the Director General, Central Council for Research in Ayurvedic Sciences, New Delhi for providing facilities during this research work.

\section{DECLARATION OF INTERESTS}

The authors declare that there is no conflict of interest.

\section{REFERENCES}

1. Guntupalli M, Mohanar R, Chandana VR, Palpu P, Annie S. Hepatoprotective effects of rubiadin, a major constituent of Rubia cordifolia Linn. J Ethnopharmacol 2006;103:484.

2. Preeti C, Shamim A, Najam AK. Herbal plants-a boon for hepatotoxicity. Asian J Pharm Clin Res 2016;9:37-40.

3. Richa T, Gaurav Sharma, Nakuleshwar DJ, Ekta Menghani. Indian medicinal plants as an effective antimicrobial agent. J Crit Rev 2016;2:69-71.

4. Cooke TCIE. The flora of presidency of Bombay. Botanical Survey of India; 1906. p. 83

5. Gamble JS. Flora of Presidency of Madras. Botanical Survey of India. Calcutta; 1967. p. 485

6. Hooker JD. Flora of British India. Botanical Survey of India. Calcutta; 1882. p. 274.

7. Jayaweera DMA. Medicinal plants used in Ceylon, Colombo: National Science Council of Sri Lanka; 1981. p. 68.

8. Hewawasam RP, Jayatilaka KAPW, Pathirana, Muddduwa LKB. Hepatoprotective effect of Epaltes divaricata extracts on carbon tetrachloride-induced hepatotoxicity in mice. Ind J Med Res 2004;120:30.

9. Anonymous. The Wealth of India, A Dictionary of Indian Raw materials and Industrial products. Publication and Information Directorate, New Delhi; Council of Scientific and Industrial Research; 1952. p. 177.
10. Rojatkar SR, Puranik VG, Tavale SS, Guru Row TN, Nagasampagi BA. Eudesmane derivatives from Epaltes divaricata. Phytochemistry 1987;26:569.

11. Harborne JB. Phytochemical methods. Jackman H. ed. London; 1973. p. 70.

12. Lala PK. Lab manuals of pharmacognosy. $5^{\text {th }}$ ed. CSI Publishers and Distributors: Calcutta; 1993.

13. Overton KH. Isolation, purification and preliminary observation in the elucidation of structures by physical and chemical methods. Bently KW. ed. Inter Science Pub: New York; 1963. p. 34.

14. OECD. Acute toxic class method guidelines 423. Ecobicon DJ. The basis of toxicity testing. CRC Press: 2nd ed. New York; 1997. p. 43.

15. Bancroft JD, Gamble G. Theory and practice of histopathological techniques. $6^{\text {th }}$ ed. Churchill Livingstone: London; 2008.

16. Henderson AR, Moss DW. Enzymes, tietz fundamental of clinical chemistry. $5^{\text {th }}$ ed. Burtis CA, Ashwood ER, WB Saunders ed. Philadelphia: USA; 2001. p. 352.

17. Tietz NW. Clinical guide to Laboratory tests. $3^{\text {rd }}$ ed. WB Saunders. eds. Philadelphia: USA; 1995. p. 20, 76.

18. Scherwin JE. Liver function, clinical chemistry, theory analysis, correlation. $4^{\text {th }}$ ed. Kaplan LA. Pena AJ, Kazmierc-zak SC. Mosby Inc. ed. St-Louis: USA; 2003. p. 492

19. Ward MK, Cockayne SWB. Saunders ed. Philadelphia: USA; 1993. p. 238.

20. Jendrassik L, Grof P. Assay on serum bilirubin. J Biochem 1938;297:81.

21. Schellong G, Wende U. Analysis of total bilirubin. Arch Kind 1960;162:26.

22. Singh R, Muftah AMS, Belkheir A. Antibacterial and antioxidant activities of Mentha piperita L. Arabian J Chem 2015;8:322-8.

23. Pradeepa M, Kalidas V, Geetha N. Qualitative and quantitative phytochemical analysis and bactericidal activity of pelargonium graveolens L'Her. Int J Appl Pharm 2016;8:7-11.

24. Mageswari S, Karpagam S. Evaluation of antimicrobial studies on root of carmona retusa (Vahl) Masam. Int J Curr Pharm Res 2015;3:60-3.

25. Boyd EH, Bereczky GM. Liver necrosis from paracetamol. Br J Pharmacol 1966;26:606.

26. Dahlin DC, Miwa GT, Lu AYH, Nelson SD. Nacetyl-pbenzoquinone imine. A cytochrome p-450-mediated oxidation product of acetaminophen. Proc Natl Acad Sci 1984;81:1327.

27. Gupta AK, Chitme H, Dass SK, Misra N. Hepatoprotective activity of Rauwolfia serpentina rhizome in paracetamol intoxicated rats. J Pharmacol Toxicol 2006;1:82.

28. Amala K, Saraswathy A, Amerjothy S. Pharmacognostic evaluation of the plant Epaltes divaricata (L.) Cass. (Asteraceae). J Med Aromat Plant Sci 2013;35:60-70.

29. Amala K, Saraswathy A, Amerjothy S. GC-MS analysis of $n$ hexane extract of Epaltes divaricata (L.) Cass. J Pharmacogn Phytochem 2013;2:33-5.

30. Kalaivani CS, Sahaya Sathish S, Janakiraman N, Johnson M. GC-MS studies on Andrographis paniculata (Burm. f.) Wall. Ex nees-a medically important plant. Med Aromat Plants 2012;1:69-74.

\section{How to cite this article}

- $\mathrm{K}$ Amala, $\mathrm{R}$ Ilavarasan, $\mathrm{R}$ Arunadevi, $\mathrm{S}$ Amerjothy. Hepatoprotective evaluation of Epaltes divaricata (L.) cass. Whole plant extracts against paracetamol-induced hepatotoxicity in rats. Int J Pharm Pharm Sci 2016;8(12):231-235. 